\title{
Necessities Laid Bare: An Examination of Possible Justifications for Peter Townsend's Purely Relative Definition of Poverty
}

\author{
Dr ANDREW DUNN \\ School of Social Sciences, Humanities and Law, Teesside University, Middlesbrough, \\ UK, TS1 3BX \\ email: andrew10840@hotmail.com
}

\begin{abstract}
The EU and OECD's use of poverty lines set at a percentage of national average income is testimony to the widespread acceptance of Peter Townsend's purely relative poverty definition. It has often been defended, including by Townsend, as a development of Adam Smith's reference to 'necessaries' differing across social contexts. This article contends that Townsend's definition is clearly inconsistent with Smith's work but entirely consistent with a passage by Wilhelm Schulz which established the term 'relative poverty' and asserted that people's material needs are proportionate to their nation's economic output per head; Karl Marx quoted that passage in a short piece that criticised Smith. A recent defence of Townsend's definition is its supposed international public endorsement in empirical studies of socially perceived necessities. A review of this evidence finds that publics, like Smith and British poverty researchers before Townsend - most notably Seebohm Rowntree - see the extent of material need as affected by social context but not proportionate to national average income. Publishing purely relative and absolute purchasing power poverty statistics together offers a way of portraying hardship levels that is balanced to reflect publics' more narrowly relative understanding of material needs.
\end{abstract}

Keywords: Adam Smith; Peter Townsend; Poverty; Necessities; Need; Marx

\section{Introduction}

British sociologist Peter Townsend defined poverty as relative deprivation, by which he meant "the absence or inadequacy of those diets, amenities, standards, services and activities which are common or customary in society" (1979: 915). Townsend's poverty line more than merely took account of a country's living standards - it was determined by those standards. Definitions and measures of poverty determined this way have been called "strictly relative" (Townsend, 1970: 13), "purely relative" (Atkinson and Bourguignon 2001: 156; Sen, 1983: 157) and "strongly relative" (Ravallion and Chen, 2011: 1251). Townsend (1979) measured poverty by linking people's material resources to 'deprivation indicators' (such as not having a refrigerator), and he was the first to propose a 
cruder yet more convenient measure that set the poverty line at a fixed percentage of national average income (see Townsend, 1962: 222). The European Union (EU) and Organisation for Economic Co-operation and Development's (OECD) adoption of purely relative poverty lines is testimony to the widespread impact of Townsend's work (see Bradshaw, 2011). Commitment to a purely relative definition is particularly strong in British social policy, with some authors presupposing its supremacy as the only acceptable definition of poverty (for example, Shildrick, 2018).

Because purely relative poverty lines are at least broadly proportionate to national income per head, they arguably overstate the richer of two countries' hardship levels. For example, using the conventional ' 60 per cent of median income' measure, Bulgaria's poverty rate was found to be lower than Britain's in 2005, despite Britain's poorer citizens' noticeably higher living standards (see Hick, 2014: 298). Comparing the same country in richer and poorer times can be seen to produce the same effect. Ireland's poverty rate increased in the 1990 when the incomes of its poorest grew less than those of others during an economic boom - an outcome dubbed the "Irish Paradox" (Hills, 2004: 42). Further arguably paradoxical findings might appear soon, due to nations' economies shrinking substantially in 2020; someone whose annual income fell during the COVID-19 crisis could be categorised as being in poverty in 2019 but not 2020, if their nation's median income fell by a higher percentage.

This article critically examines possible justifications for Townsend's purely relative definition, and in doing so it highlights neglected differences between purely relative and more narrowly relative understandings of poverty. Possible justifications for the purely relative definition centre on its underpinning assumption that people's material needs are at least broadly proportionate to their nation's average income. The first part focuses on what justifications Townsend offered for his definition. It starts by revisiting the definition's emergence and Townsend's initial justification that it was a development of Adam Smith and Alfred Marshall's view that 'necessaries' differ according to social context. It then discusses Townsend's later responses to his critics, which implied that the extent of socially created need matches real national output. The second part looks at a recent justification of the purely relative poverty definition - the hitherto undisputed claim that Townsend's definition is consistent with survey findings about what people consider to be 'necessities' (see Bramley and Bailey, 2018; Lansley and Mack, 2013). Evidence reviewed is from the four Breadline Britain/Poverty and Social Exclusion (PSE) surveys (1983, 1990, 1999 and 2012), two comparative international studies (of European [Eurobarometer, 2007] and West African [Pomati and Nandy, 2020] countries), and nine other surveys of socially perceived necessities from around the world. A conclusion reflects on the article's main points and considers their possible implications for current debates about poverty reduction and measurement. 


\section{Townsend's justifications for his purely relative definition of poverty}

\section{Townsend on poverty definition, and the Adam Smith poverty fallacy}

Seebohm Rowntree's three studies of York, England in 1899, 1936 and 1950 set the scene for Townsend's intervention on poverty definition. Townsend (1954) noted the disparity between Rowntree's (1901: 86) absolutist definition (lacking "the minimum necessaries for the maintenance of merely physical efficiency" and his empirical work's use of working-class standards specific to time and place. Indeed, from 1936 the budgets he based his poverty lines on allowed for the purchase of a "wireless" (radio) (Rowntree, 1941: 28). Moreover, Rowntree's detailed assessments of human needs recognised that people's optimal calorie requirement varies according to their social role, and that the type and cost of food they tend to eat varies according to social context (see Rowntree, 1937: 53-85).

Veit-Wilson's (1986) influential article showed that Rowntree deployed his absolutist poverty definition to ensure his individualist critics could not claim real poverty did not exist; because Rowntree neither qualified nor elaborated upon his definition (poverty definition was not widely debated at the time) his empirical work has not been widely recognised as "relativist" (Veit-Wilson, 1986: 70). Veit-Wilson (1986: 91, 93) cited Townsend's comparison of Rowntree's "narrowly relativistic" empirical work (see Townsend, 1979: 38) with his own "thoroughgoing relativism" (see Townsend, 1979: 33). Townsend's characterisation of the two's work has gone unchallenged, as it is accepted that Rowntree "did not try to argue that the poverty line itself should automatically move upwards in line with the general standard of living" (Harris, 2000: 77). As Townsend (1970: 12-13) observed, Rowntree's upward revisions to his poverty line "fell midway between price and wage increases and, accordingly, he found smaller proportions in poverty at successive dates than he would have found if a strictly relative standard had been used".

In his early critique Townsend noted that Rowntree had not explained why some items necessary for social participation, such as "newspapers", were included in his budget calculations but not others, such as "cosmetics" (Townsend, 1954: 131). Townsend at first appeared to merely advocate incorporating a more complete and generous understanding of working-class people's needs into what poverty means:

A few drinks in a pub on a Saturday night after watching the local football match may be as necessary, in the conventional sense, to membership of the poorest stratum of society as a Savile Row suit and business meetings over lunch at the Savoy to membership of a wealthier stratum (Townsend, 1954: 133)

However, his subsequent definition asserted that people "are in poverty" if they "fall seriously short of the resources commanded by the average individual or family in the community in which they live" (Townsend, 1962: 224). 
Townsend's focus on the entire community's standards was a clear departure from Rowntree's work. When Townsend later referred to this difference between them, he alluded to having a broader sociological canvas. Citing Seebohm Rowntree as an example, he observed that "Much of the British liberal tradition in social sciences involves the portrayal of the poor relative to the secure working class, rather than the full range of social stratification"; he contrasted this tradition with Friedrich Engels' (1892) 'Condition of the Working Class in England' which "perceives so clearly the structural relationship between privilege and want" (Townsend, 1975: 32). Because Townsend sought to include all social ranks' living conditions in his poverty analysis, he favoured 'mean'-based income poverty lines - a "low" line set at 80 per cent of mean income and a "very low" line at 50 per cent (Townsend, 1979: 248); he explained that if the "median" (i.e. one based on the incomes of the 50 th $/ 51 \mathrm{st}$ percentile) were used "the income 'capacity' of a country might be concealed in cross-national comparisons if a tiny percentage of the population have exceptionally high incomes" (ibid: 248).

Despite Townsend's early socialist writing railing against the post-war cross-party political consensus view that pursuing economic growth should take precedence over reducing economic inequality (for example, Townsend, 1958), he portrayed his poverty definition as a development of earlier contributions by non-socialists. When offering justification for shifting the meaning of poverty, he quoted the following comments by Adam Smith and Alfred Marshall (see Townsend, 1962: 219):

By necessaries I understand, not only the commodities which are indispensably necessary for the support of life, but whatever the custom of the country renders it indecent for creditable people, even of the lowest order, to be without. (Smith, 1776, [2012]: 871)

Every estimate of necessaries must be relative to place and time. (Marshall, 1890, [1946]: 57)

Townsend stated that "In our own day there is everything to be said for returning unashamedly to the broad theoretical outlook of these early economists" (Townsend, 1962: 219). The same connection between Smith's work and Townsend's purely relative definition has been made countless times since, including in landmark poverty publications (such as Atkinson, 1970: 17; Coates and Silburn, 1973: 36; Mack and Lansley, 1985: 26-7) and when a Conservative Party think tank was converted to Townsend's definition (Clark and Franklin, 2006: 6). These citations continue (Lister, 2021: 30; Portes, 2020: 31). Until now no author has argued that Smith and Marshall's position is not consistent with Townsend's purely relative definition but is consistent with the more narrowly relative view of poverty that prevailed before Townsend's work first appeared. 
There is no evidence that the way poverty was investigated before Townsend's intervention was inconsistent with Smith's view. Smith (2012 [1776]: 871) restricted his 'necessaries' to what "nature... renders necessary" plus time-and-place specific basics which, if absent, would publicly shame the "lowest rank of society"; thus, he deemed "sugar", "tea" and "ale" nonnecessaries (p.872). Smith's oft-cited (including by Townsend, 1979: 32) example of a "linen shirt", which labourers in most of Eighteenth Century Europe needed despite it being unavailable to ancient Greeks and Romans (2012 [1776]: 871), is echoed in Rowntree's (1901: ix) “workmen's budgets", which allowed for the cost of "clothing" appropriate for "obtaining respectable employment" (Rowntree, 1901: 108).

The measurement of poverty was an uncontroversial topic before Townsend's time, with Rowntree following Charles Booth's empirical approach and Arthur Bowley merely refining Rowntree's methods (Veit-Wilson, 1986). As Townsend (1954: 131) noted after referring to Rowntree's 1899 survey, "studies that followed in the next forty years" used "standards ... for measuring poverty" that "were broadly the same". If poverty authors had all contradicted the view of the era's most notable British economist (and founder of neoclassical economics) Alfred Marshall, who described Smith as a "genius" (Marshall, 1946: 626), this contradiction might have been documented before Townsend's time. Yet there is no evidence of this in surviving papers, such as correspondence between Marshall and his friend Bowley (see Pigou, 1925, 427-30).

A key premise of Townsend's purely relative poverty definition, and perhaps his writing's most striking characteristic (see, especially, 1958; 1970; 1975), opposes a key theme of Adam Smith's 'Wealth of Nations' - that a rise in real national average income (per se, and even if resource distribution remains unchanged) improves the lives of a nation's poorest citizens. The theme is emphasised in its 'Introduction' (2012 [1776]: 3-5) and returned to numerous times; for example, in a less known reference to linen he enthuses about capitalist (what he called 'commercial') society's "great improvements in the coarser manufactories of both linen and woollen cloth" which "furnish the labourers with both cheaper and better clothing" (2012 [1776]: 83). The theme surfaces in Smith's other major works (see Gilbert, 1997); he claims that commercial society's economic growth will eventually deliver an "opulence" that "extends to the lowest member of the community" (Smith, A, 1978 [1762-66]: 564), whereby "poverty is easily avoided" (Smith, A, 1976 [1759]: 205). Furthermore, Townsend's support for large-scale redistribution contrasts sharply with Smith, who was entirely uncritical of class structure and saw income inequality as an essential stimulant to the economic growth that helps all (see Baum, 1992; Smith, C., 2020: 176). Even authors seeking to rescue Smith from some of his right-wing admirers' portrayals have not challenged these assertions (examples include Fleischacker, 2004; McLean, 2006). 
Marshall shared Smith's view that distribution-neutral increases in real national income per head improve people's lives. Rowntree's biographer Asa Briggs (1961: 24) discovered that “among Rowntree's surviving papers are copies of a bundle of Marshall's early letters to the press", including one entitled "Wealth and Want: Do They Increase Together?" This supposed 'letter' appears, in fact, to have been an 1883 lecture, given in Bristol, England, and published in local newspapers the following day (see Marshall, 1969). As its title suggests, it was written in opposition to Henry George's (1879) book. In the lecture, Marshall (1969) pointed to improvements in working class life caused by capitalism, such as "railways", "gaslight in towns" (p.188), and the value of workingclass London wages increasing from "two pecks of wheat" in 1730 to "about five" at present (p.186). Rowntree's retention of this lecture by Marshall (who Briggs [1961: 24] described as an "outstanding guide" to Rowntree), shows his awareness of counter-arguments to Townsend's.

\section{Townsend on socially created need, and Wilhelm Schulz on 'relative poverty'}

Amartya Sen prompted Townsend's only published response to criticism of his 'purely relative' definition for its implication that society-wide, distribution-neutral increases in real income do not improve people's lives:

In any purely relative view ... gains shared by all tend to get discounted ... a general decline in prosperity with lots of additional people in misery ... need not show up as a sharp increase in poverty... we have been made to abandon here an essential characteristic of poverty, replacing it with some imperfect representation of inequality (Sen, 1983: 156)

Townsend's (1985a) reply acknowledged no merit in these points, and it appeared to imply that such 'gains shared by all' are nullified by a corresponding increase in socially created need. The following assertion, interpretable as responding to Sen's points, expresses his view that the extent of poverty should be understood (and measured via detached scientific observation) as needs society has created but failed to satisfy:

The essence of the approach I am endeavouring to develop is that society, and especially the State, is creating or "manufacturing" as well as reconstituting needs at the same time as it is determining the allocation of resources in the first place (and not just the redistribution of income) with which those needs can or will be met. Our understanding of changes in the extent of poverty depend fundamentally on scientific exposition of this dual process. (Townsend, 1985a: 663)

This was a reiteration of Townsend's (1979: 917) structuralist view that he quoted in response to Piachaud's (1981) point that poverty cannot be measured objectively (Townsend, 1981: 477). Both replies mentioned sociology. Townsend's 
(1985a: 659) "sociological” reply to Sen attributed the latter's underestimation of socially created need to "individualism which is rooted in neo-classical economics” (ibid: 668). Townsend's (1981: 477) reply to Piachaud connected his own work to "the material and often radical basis of much present sociology".

Yet Townsend's (1979) major work did not name sociologists who shared his view on the extent of socially created need. Its index did not feature 'need/s', and his discussion of manufactured needs was limited to mentions of the role of advertising (p.58-59) and the influence of the rich on prevailing lifestyle preferences (p.366-67). These two points chime with his extended poverty definition's reference to "activities and living conditions" that are "widely encouraged and approved" (p.31), but he connected neither point to any relevant academic publications, such as Marcuse (1964). Only in his later review of Mack and Lansley's (1985) book, when reiterating his view of the general public's "socially conditioned" and hence "severely limited conception of need" (Townsend, 1979: 914), did Townsend invoke Engels' term (see Starks and Junisbai, 2007: 1568) "false consciousness", noting that individuals might not be "aware of their enslavement" (Townsend, 1985b: 44). Indeed, Townsend's account of socially constructed need is similar to Karl Marx's.

Marx probably developed his position on need from Hegel's (1975) [1820] view that human needs tend to multiply (see Lebowitz, 2003: 31). As Lebowitz (2003: 32-44) notes, Marx split human needs into 'necessary needs' (the costs of maintaining labour, which are satisfied) and 'social needs' (further needs created by expanded production, which are not satisfied). Reminiscent of Townsend, Marx saw the gap between these satisfied and unsatisfied needs as demarcating the depth of workers' 'immiseration'. With production and needs expanding in parallel, workers are therefore no nearer to satisfying their social needs, yet they have been sucked further into a system that exploits them both as workers and consumers (see also Coates and Bodington, 1976):

... every person speculates on creating a new need in another, so as to drive him to a fresh sacrifice, place him in a new dependence and to seduce him into a new mode of gratification... The increase in the quantity of objects is accompanied by an extension of the realm of the alien powers to which man is subjected. (Marx, 2011 [1844]: 82) ${ }^{1}$

Marx's purely relative understanding of human needs (see also chapter six of 'Wage Labour and Capital' [see Marx, 1970: 82-4]), is matched by the following passage he quoted:

For just because total production rises - and in the same measure as it rises - needs, desires and claims also multiply and thus relative poverty can increase whilst absolute poverty diminishes. The Samoyed living on fish oil and rancid fish is not poor because in his secluded society all have the same needs. But in a state that is forging ahead, which in the course of a decade, say, increased by a third its total production in proportion to the population, the worker who is getting as much at the end of ten years as 
at the beginning has not remained as well off, but has become poorer by a third. (Schulz, 1843: 65-6, quoted in Marx, 2011 [1844]: 18)

Wilhelm Schulz not only used the phrase 'relative poverty' ("relative armuth" in the original German [1843: 66]) which Smith did not, he established the following idea that was central to Townsend's work: because material needs grow with economic output per head, the extent of a person's poverty is determined by her/his position in relation to national average income (though, in the quotation, perhaps Schulz meant that the worker had become poorer by a quarter, not a third). Therefore, Wilhelm Schulz, not Adam Smith, must be considered the originator of the purely relative poverty idea Townsend later developed.

Marx's 'Wages of Labour' book (2011 [1844]: 12-23), which included the Schulz 'relative poverty' quotation, appears to have been provoked by Smith's similarly titled 'Of the Wages of Labour' (2012 [1776]: 69-92). In it, Smith had contrasted growing economies with "stationary" economies such as China, commenting that "The poverty of the lower ranks of people in China far surpasses that of the most beggarly nations in Europe" (p.76). Marx quoted Smith's view that "No society can surely be flourishing and happy, of which the far greater part of the members are poor and miserable" (2012 [1776]: 83) and replied (2011 [1844]: 15): "according to Smith, a society is not happy, of which the greater part suffers - yet even the wealthiest state of society leads to this suffering of the majority". This captures their opposing views on the condition of the working class in a growing capitalist economy: for Marx it is immiseration, for Smith improvement. Indeed, this article's separation of Marx, Townsend and Schulz's purely relative views around poverty and need from the more narrowly relative positions of Smith, Rowntree and Marshall has served to highlight an accompanying difference of opinion about whether a distribution-neutral increase in an unequal society's real average income delivers actual social improvement.

Despite the gap Townsend noted between his and the British public's view on the extent of need (see above), and despite British Social Attitudes surveys "consistently" finding that "fewer than one-third... accept a thoroughgoing relativist definition of poverty" (Lister, 2021: 40), Townsend's view of what constitutes poverty is nevertheless said to be consistent with evidence of what people in Britain and elsewhere have classed as necessities. In the next part this evidence is re-examined.

The 'socially perceived necessities' justification for Townsend's purely relative definition of poverty

\section{Empirical evidence and the purely relative definition}

In a rare discussion of possible evidential justifications for a purely relative measure/definition of poverty, Ravallion (2016: 107-9) insisted it must satisfy at 
least one of two assumptions: 1 . The relative cost of social inclusion is the same in any society; 2 . Human wellbeing is unaffected by absolute material resources at a given relative position (as implied by Marx). Ravallion suggests the first is invalid because the relative cost will be lower in richer countries (see p.108). He dismisses the second as "a very strong assumption" (p.109); like Sen's (1983), Ravallion's expertise is "rooted in third world economies" (Townsend, 1985a: 663), where suffering is often seen to be alleviated by rising prosperity. For example, India's extreme (or 'absolute') poverty rate (measured as below $\$ 1.90$ per day at 2011 prices, at Purchasing Power Parity [PPP]) declined from 46 per cent (1993) to 21 per cent (2011), almost entirely due to economic growth (see Bourguignon, 2019: 223). Conversely, in the richest countries the comparative infrequency of emergency material conditions serves to highlight the impact of relative disadvantage upon, for example, subjective wellbeing (see Frey and Stutzer, 2002). Evidence of what the world's publics consider to be necessities can shed light on the validity of Ravallion's first assumption; it will be supported if differences between what publics in different countries (and eras) regard as necessities are broadly consistent with respective differences in real national income per head.

\section{Mack and Lansley's (1985) 'socially perceived necessities'}

Research on publicly determined necessities, often called the 'consensual approach', was pioneered by Joanna Mack and Stewart Lansley. They defined poverty as "an enforced lack of socially perceived necessities" (Mack and Lansley, 1985: 45). Lists of possible necessities are developed among focus groups, but findings avoid group dynamic effects because they require endorsement by a majority of survey respondents. Respondents are asked to distinguish 'necessities' from items that "might be 'desirable' but [are] not necessary" (Mack and Lansley, 1985: 52).

Mack and Lansley's approach incorporated Piachaud's (1981) criticism that Townsend's (1979) 'deprivation indicators' included items that people might consider unimportant or choose to go without. Mack and Lansley (1985: 36-7) rejected Townsend's “concept of 'need' that is outside people's feelings and experiences", suggesting that, therefore, his work "tells us a great deal about inequality... But it tells us nothing about poverty".

Nevertheless, PSE authors claim that Townsend's "notion of poverty" finds "strong public support" from research using the "consensual deprivation approach" (Bramley and Bailey, 2018: 344), and Lansley and Mack (2013: 23) maintain that "surveys in poor, middle income and rich countries" show people are "committed relativists". Arguing against Niemietz's (2011: 108) rejection of Ravallion's first assumption, Lansley and Mack (2013) noted that "Niemietz produces no real evidence" (p.5) before pointing to Breadline Britain/PSE items voted necessities in 1999 but not 1983 ("a telephone" and "an outfit for special 
occasions", p.6). Until now the extent to which socially perceived necessities evidence is consistent with Townsend's purely relative view of poverty and material need has not been explored in detail. This review draws upon all known surveys that followed Mack and Lansley's approach. Its main question is: are countries' socially perceived necessities at least broadly proportionate to their purchasing power per head?

\section{The Breadline Britain/PSE studies}

Breadline Britain/PSE surveys offer a unique opportunity to monitor changes over several decades to a country's socially perceived necessities ${ }^{2}$. Since 1999 the project has included a specific children's study; so for better comparability only adult necessities are discussed here, and this applies to all research reviewed below. To aid comparison, Table 1 collates all years' findings.

Evidence indicates that socially perceived necessities' value has not increased by as much as either the 77 per cent (median) or 88 per cent (mean) that real disposable income increased between 1983 and 2012 (ONS, 2020: 3). Only once was an item which was voted a necessity in 2012 voted a non-necessity in one of the earlier surveys (a telephone, which scored 43 per cent in 1983); yet on 14 occasions a 2012 'non-necessity' was earlier voted a necessity. The 13 items that were not included in 1983 yet voted necessities in 2012 were not 'new' - all were available in 1983 (neither a mobile phone nor internet access was voted a necessity in $\mathbf{2 0 1 2}$, although both votes were considerably higher than in 1999).

The PSE team suggest that the $\mathbf{2 0 1 2}$ fall in the number of socially perceived necessities reflects "reduced public expectations" due to harsher economic times, pointing out that "median incomes in 2011/12 were almost identical to those in 2001/o2 in real terms" (Bailey and Bramley, 2018: 10). Yet real median incomes were 11 per cent higher in 2011/12 than in 1998/99 (Carr et al., 2014: 3). Furthermore, real median income growth of over a quarter between 1983 and 1990 did not produce a spike in items voted necessities; only the two Lansley and Mack (2013) mentioned in response to Niemietz (2011) passed 50 per cent, increasing their votes by just 13 and six percentage points.

Thus, Breadline Britain/PSE evidence does not support the view that socially perceived needs grow broadly in parallel with real national income per head. This conclusion sits well with UK aggregate savings (and hence mortgage demand) being much larger during periods of growing prosperity; the Department of Housing, Communities and Local Government (2018: 7) estimated that, because of this savings effect, between 1991 and 2016 each one per cent increase in real disposable income precipitated a two per cent rise in real house prices. 
TABLE 1. Percentages who voted items a 'necessity' for adults, and percentages who indicated they did not have a 'necessity' because they could not afford it

\begin{tabular}{|c|c|c|c|c|c|c|c|c|}
\hline \multirow{3}{*}{$\begin{array}{l}\text { Item } \\
\text { Heating to warm living areas of the home } \\
\text { if it's cold }\end{array}$} & \multicolumn{8}{|c|}{$\begin{array}{l}\% \text { indicating item is a necessity } \\
\text { (Left Columns) and \% saying they } \\
\text { lack the item because they cannot } \\
\text { afford it (Right columns) }\end{array}$} \\
\hline & \multicolumn{2}{|c|}{1983} & \multicolumn{2}{|c|}{1990} & \multicolumn{2}{|c|}{1999} & \multicolumn{2}{|c|}{2012} \\
\hline & 97 & 6 & 98 & 3 & 94 & 1 & 96 & 9 \\
\hline Indoor Toilet & 96 & 1 & 97 & o & & & & \\
\hline Damp-free home & 96 & 8 & 97 & 2 & 93 & 6 & 94 & 10 \\
\hline Bath (not shared with another household) & 94 & 2 & 95 & o & & & & \\
\hline Beds for everyone in the household & 94 & 1 & 95 & 1 & 95 & 1 & & \\
\hline Public transport for one's needs & 88 & 3 & & & & & & \\
\hline A warm water-proof coat & 87 & 7 & 91 & 4 & 85 & 4 & 79 & 4 \\
\hline Self-contained accommodation & 79 & 3 & & & & & & \\
\hline Two pairs of all-weather shoes & 78 & 11 & 74 & 4 & 64 & 5 & 54 & 8 \\
\hline Refrigerator & 77 & 1 & 92 & 1 & 89 & o & & \\
\hline Carpets in living rooms and bedrooms & 70 & 2 & 78 & 2 & 67 & 3 & & \\
\hline Celebrations on special occasions such as Christmas & 69 & 4 & 74 & 4 & 83 & 2 & 80 & 4 \\
\hline A roast meat joint or its equivalent once a week & 67 & 7 & 64 & 6 & 56 & 3 & 36 & \\
\hline A washing machine & 67 & 5 & 73 & 5 & 76 & 1 & 82 & 1 \\
\hline New, not second-hand, clothes & 64 & 6 & 65 & 4 & 48 & & 46 & \\
\hline A hobby or leisure activity & 64 & 9 & 67 & 6 & 78 & 7 & 70 & 8 \\
\hline Two hot meals a day (for adults) & 64 & 4 & 90 & 1 & 91 & 1 & 91 & 3 \\
\hline Meat or fish every other day & 63 & 9 & 77 & 3 & 79 & 3 & 76 & 5 \\
\hline Presents for friends or family & 63 & 5 & 69 & 4 & 56 & 3 & 46 & \\
\hline $\begin{array}{l}\text { A holiday away from home for one week } \\
\text { a year, not with relatives }\end{array}$ & 63 & 23 & 54 & 20 & 55 & 18 & 42 & \\
\hline A garden & 55 & 5 & & & & & & \\
\hline A television & 51 & 0 & 58 & 1 & 56 & 1 & 51 & 0 \\
\hline $\begin{array}{l}\text { A 'best outfit' for special occasions } \\
\text { ('social occasions' in ' } 99 \text { \& '12) }\end{array}$ & 48 & & 54 & 8 & 51 & 4 & 38 & \\
\hline A telephone & 43 & & 56 & 7 & 71 & 1 & 77 & 2 \\
\hline A dressing gown & 38 & & 42 & & 34 & & & \\
\hline An evening out once a fortnight (adults) & 36 & & 42 & & 37 & & 34 & \\
\hline Friends/family round for a meal once a month & 32 & & 37 & & 64 & 6 & 45 & \\
\hline A car & 22 & & 26 & & 38 & & 44 & \\
\hline A packet of cigarettes every other day & 14 & & 18 & & & & & \\
\hline A decent state of decoration in the home & & & 92 & 15 & 82 & 14 & 69 & 20 \\
\hline Insurance of contents of dwelling & & & 88 & 10 & 79 & 8 & 69 & 12 \\
\hline Daily fresh fruit and vegetables & & & 88 & 6 & 86 & 4 & 83 & 7 \\
\hline $\begin{array}{l}\text { Regular savings of } £_{10} \text { a month for "rainy days" } \\
\left(\mathfrak{E}_{20} \text { in } 2012\right)\end{array}$ & & & 68 & 30 & 66 & 25 & 52 & 33 \\
\hline Coach/Train fares to visit friends four times a year & & & 39 & & 38 & & 27 & \\
\hline Holidays abroad annually & & & 17 & & 19 & & 18 & \\
\hline A meal in a restaurant/pub, monthly & & & 17 & & 26 & & 25 & \\
\hline Video (VCR) & & & 13 & & 19 & & & \\
\hline Home computer & & & 5 & & 11 & & 40 & \\
\hline Dishwasher & & & 4 & & 7 & & 10 & \\
\hline
\end{tabular}




\begin{tabular}{|c|c|c|c|c|c|c|}
\hline \multirow{3}{*}{$\begin{array}{l}\text { Item } \\
\text { Visiting friends or family in hospital }\end{array}$} & \multicolumn{6}{|c|}{$\begin{array}{l}\text { \% indicating item is a necessity } \\
\text { (Left Columns) and \% saying they } \\
\text { lack the item because they cannot } \\
\text { afford it (Right columns) }\end{array}$} \\
\hline & 1983 & 1990 & 1995 & & 2012 & \\
\hline & & & 92 & 3 & 90 & \\
\hline Medicines prescribed by doctor & & & 90 & 1 & & \\
\hline Replace or repair broken electrical goods & & & 85 & 12 & 86 & \\
\hline Visits to friends or family & & & 84 & 2 & & \\
\hline Attending weddings, funerals & & & 80 & 3 & 78 & \\
\hline Appropriate clothes for job interviews & & & 70 & 4 & 69 & \\
\hline Deep freezer/fridge freezer & & & & 2 & & \\
\hline $\begin{array}{l}\text { A small amount of money to spend on self, } \\
\text { weekly, not on family }\end{array}$ & & & 59 & 13 & 42 & \\
\hline Replace worn out furniture & & & 54 & 12 & & \\
\hline Dictionary & & & 53 & 5 & & \\
\hline Attending a place of worship & & & 42 & & 29 & \\
\hline Having a daily newspaper & & & 30 & & & \\
\hline Microwave oven & & & 23 & & & \\
\hline Tumble Dryer & & & 20 & & & \\
\hline Going to the pub once a fortnight & & & 20 & & 17 & \\
\hline CD Player & & & 12 & & & \\
\hline Mobile phone & & & 7 & & 40 & \\
\hline Access to the Internet & & & 6 & & 41 & \\
\hline Satellite television & & & 5 & & & \\
\hline All recommended dental work/treatment & & & & & 82 & 17 \\
\hline Curtains or window blinds & & & & & 71 & \\
\hline A table, with chairs, at which all the family can eat & & & & & 64 & \\
\hline Taking part in sport/leisure activities or classes & & & & & 56 & 10 \\
\hline $\begin{array}{l}\text { Regular payments into an occupational or } \\
\text { private pension }\end{array}$ & & & & & 51 & \\
\hline Hair done or cut regularly & & & & & 35 & \\
\hline $\begin{array}{l}\text { Going to a cinema, theatre or music event } \\
\text { once a month }\end{array}$ & & & & & 15 & \\
\hline
\end{tabular}

Source: Breadline Britain/PSE findings, (from Mack and Lansley, 1985: 54, 89; Gordon and Pantazis, 1997: 297; Gordon et al., 2000: 14-15; Lansley and Mack 2015: 19, 42).

\section{Two Comparative studies: West Africa and Europe}

This section asks if two groups of countries' socially perceived necessity lists vary as much as their average incomes. Pomati and Nandy (2020) compared five similar surveys from Gabon in 2005, Benin in 2006, Mali in 2006, Guinea in 2007, and Liberia in 2010 (Guinea is excluded from discussion here because few items were voted on). The list of necessities voted on in all four remaining countries was: a home, at least two pairs of shoes, a change of clothes, radio, tables and beds, being able to buy a TV, meat or fish every day, three meals every day, cereals or tubers every day, body care (soaps, hair styling etc.), able to take a taxi in an emergency, and having access to water and electricity. All were voted 
necessities by more than 75 per cent in Benin, Liberia, and Mali, and all scored over 50 per cent in Gabon except cereals/tubers at 40 per cent (see Pomati and Nandy, 2020: 114-15). In comparing these findings to Britain's, note countries' Gross National Income (GNI) per head at PPP at 2017 prices in the surveys' years: Benin (\$2596), Gabon (\$14164), Liberia (\$1293) and Mali (\$1914)3. Britain's in 2012 was $\$ 42362$. The fact that electricity, a radio and a TV were all voted as necessities in four countries with a combined GNI per head at PPP of less than half that of Britain's indicates that countries' socially perceived necessity lists vary much less than their average incomes. One other study from a poorer nation is consistent with this view, while another is not. 'Having a radio or TV' was voted a necessity in Bangladesh in 2000 (Ahmed, 2007: 59) which had a GNI per head at PPP of \$2002 then, but neither TVs nor radios were voted necessities in the Solomon Islands in 2016 (Fifita et al., 2017) where it was \$2225 in 2017 .

To indicate the European comparative study's (see Eurobarometer, 2007 ${ }^{4}$ ) overall findings (from $27 \mathrm{EU}$ states plus Croatia, which joined shortly afterwards), here are the 14 adult necessities voted for by over 50 per cent of all respondents: medical care when needed ( 77 per cent), buying medicine when needed (74), indoor flushing toilet (69), no leaking roof or dampness (68), bedding for everyone (68), hot water (67), medical equipment when needed (67), warm winter coat (65), own bath or shower (63), warm home (62), medical and dental checks (62), refrigerator (58), two pairs of shoes appropriate to the climate (58), no risk of eviction from home (57). Items below 50 per cent include new (not second hand) clothes (30), colour TV (19) and a car (17). Considering both comparative studies, findings from one of the world's richest regions and one of its poorest do not differ anywhere near enough to give support to the view that socially perceived need is proportionate to national average purchasing power.

\section{Studies of unmet socially perceived need}

The more a country's level of unmet need matches its level of relative poverty, rather than its national income per head or its 'absolute poverty' rate, the more socially perceived necessities are consistent with a purely relative definition. Findings from all known surveys that asked respondents if they wanted but could not afford their country's socially perceived necessities are included in Table 2. 'Unmet need' figures are produced by aggregating the percentages lacking each socially perceived necessity due to being unable to afford it, and then dividing this aggregated figure by the total number of necessities. Relative poverty data is scarce outside the OECD, so Gini coefficient measures of income inequality are used. While this is a limitation of the review, income inequality is a good proxy as it correlates very strongly (0.8-0.9) with relative poverty rates (see Karagiannaki, 2017: 11). 
TABLE 2. Absolute poverty, inequality, national income per head and unmet need in various countries

\begin{tabular}{|c|c|c|c|c|c|}
\hline Country & $\begin{array}{l}\text { Year of } \\
\text { survey }\end{array}$ & $\begin{array}{c}\text { Absolute poverty rate }(\% \text { of } \\
\text { population living on }<\text { US } \$ 1.90 \\
\text { per day at } 2011 \mathrm{PPP})\end{array}$ & $\begin{array}{c}\text { Income inequality } \\
\text { (Gini Coefficient, } \\
0=\text { complete equality, } \\
1=\text { complete inequality) }\end{array}$ & $\begin{array}{l}\text { National income per head } \\
\text { (GNI at PPP, in } 2017 \text { US\$) }\end{array}$ & $\begin{array}{l}\text { Unmet need (mean \% lacking a } \\
\text { socially perceived necessity because } \\
\text { they cannot afford it) }\end{array}$ \\
\hline \multirow[t]{2}{*}{ Australia } & 2006 & $0.4(2008)$ & $0.35(2008)$ & 41485 & 6.6 \\
\hline & 2010 & 0.3 & 0.35 & 43580 & 5.7 \\
\hline Benin & 2006 & $49.5(2015)$ & $0.46(2005)$ & 2596 & 17.8 \\
\hline \multirow[t]{4}{*}{ Britain } & 1983 & $0.7(1986)$ & $0.32(1986)$ & $23181^{1}$ & 5.2 \\
\hline & 1990 & $0.2(1991)$ & $0.36(1991)$ & 30456 & 5.9 \\
\hline & 1999 & 0.2 & 0.35 & 36877 & 5.4 \\
\hline & 2012 & 0.2 & 0.32 & 42362 & 9.6 \\
\hline Hong Kong & 2012 & Not known & $0.47^{2}(2016)$ & 53785 & 6.4 \\
\hline Romania & 2013 & 7.2 & 0.37 & 21788 & 27.2 \\
\hline Solomon Is. & 2016 & $25.1(2013)$ & $0.47(2013)$ & $2225(2017)$ & 45.0 \\
\hline South Africa & 2006 & $16.9(2008)$ & $0.65(2005)$ & 11711 & 31.5 \\
\hline Sweden & 1992 & $0.2(1992)$ & 0.25 & 31876 & 3.1 \\
\hline
\end{tabular}

Sources: World Bank/various publications - Australia - Saunders and Wong (2010: 14-18); Benin - Nandy and Pomati (2015: 699); Britain - Mack and Lansley (1985: 54, 89); Gordon and Pantazis (1997: 297); Gordon et al. (2000: 14-15); Lansley and Mack (2015: 19, 42); Hong Kong - Wong and Saunders (2012: 26-34); Romania - Stănescu and Dumitru (2017: 16-17); Solomon Islands - Fifita et al. (2017: 4-10); Sweden - Hallerod (1994: 11); South Africa - Wright and Noble (2013: 153-54); Notes: ${ }^{1}$ Derived using ONS economic growth figures, mid-1983 to mid-1990 ${ }^{2}$ Estimate from Oxfam: https://www.oxfam.org.hk. 
The four countries with easily the highest rates of unmet socially perceived need are the four with the highest levels of absolute poverty and lowest national incomes per head (Table 2). Inequality is not consistent with levels of unmet need, although it appears to influence them; Sweden's exceptionally low unmet need ( 3.1 per cent) can be attributed to not only its economic success, but also the low economic inequality of a country governed from 1932 to 1976 by a Party linked to trade unions (Gould, 1988). Differences in countries' perceived necessities appear to stem from differences in material conditions; washing machines and refrigerators were considered necessities in the richest six countries but not the poorest two. Nevertheless, evidence in Table 2 is not consistent with a purely relative definition of poverty, as levels of unmet need are more associated with absolute material conditions than they are with economic inequality.

\section{Conclusion}

Peter Townsend's poverty definition is traceable to Wilhelm Schulz's writing and is underpinned by a purely relative view of human material need favoured by both Schulz and Karl Marx. The definition is often portrayed as a development of, and a reconnection with, Adam Smith's work, despite Smith being perhaps the person in all history most associated with the idea the purely relative definition implicitly rejects: that a distribution-neutral increase in real national income per head improves the lives of a country's poorest citizens. The fallacy that Townsend returned the meaning of poverty to what Smith believed in has given his concept credibility beyond its disciplinary, ideological and economic developmental support bases: Smith is associated with economics, favouring capitalism over socialism, and a country at an early stage of industrial development.

The purely relative definition's reputation was further bolstered by its supposed public endorsement in empirical studies of socially perceived necessities. Yet these findings strongly indicate that, like Smith, Marshall and Rowntree, publics see the extent of need as affected by social context, but not proportionate to average national material standards. Their more narrowly relative view carries the implication that poverty can be reduced not only by tackling economic inequality, but also by economic growth. Nevertheless, apparent public disagreement with Townsend's definition should not be construed as public satisfaction with contemporary economic inequality levels: 56 per cent of Britons in 2018 both agreed the "gap between those with high and low incomes" is "too large" and rejected a poverty definition like Townsend's'.

Because socially perceived necessity research findings reflect people's feelings and experiences, they can deliver a meaningful 'narrower than purely relative' poverty measure. However, away from the consensual method a meaningful compromise between purely relative and absolute poverty measures 
seems less likely. Given Townsend's sociological background (and his heavy influence on academic social policy - Deacon, 2002) it is unsurprising that attempts to reconcile the two have been confined to economics (examples include Atkinson and Bourguignon, 2001; Ravallion and Chen, 2011). These compromises require judgements on how much weight to assign to social context and how much to absolute purchasing power, so they are inevitably 'caught between two stools'. It might be better to view absolute and purely relative approaches as irreconcilable yet complementary. They each deliver unconvoluted findings from one end of the absolute-relative poverty definition continuum. Publishing these findings together offers a way of portraying hardship levels that is balanced to reflect publics' more narrowly relative understanding of material needs. Social policy authors already advocate deploying multiple (usually all purely relative) poverty measures, including those that gauge severer conditions that are likely to have become more widespread amid the COVID-19 crisis (Edmiston, 2021).

\section{Acknowledgements}

The author thanks two anonymous reviewers for their helpful comments on earlier drafts.

\section{Competing Interests}

The author declares none.

\section{Notes}

1 Marx's publications are archived here: www.marxists.org

2 The 'Minimum income standards' project (see Davis et al., 2020) began in 2008 and has no survey element; like the consensual studies reviewed here it has exposed public views around need that are far from absolutist.

3 These World Bank figures are available here: https://data.worldbank.org/indicator/NY.GDP. PCAP.PP.KD

4 The European findings can be viewed here: https://www.poverty.ac.uk/system/files/poverty/ eurobarometer_heatmap.html

5 Calculated using British Social Attitudes Survey data.

\section{References}

Ahmed, M. (2007), 'Consensual Poverty in Britain, Sweden and Bangladesh: A Comparative Study', Bangladesh e-Journal of Sociology, 4, 2, 56-77.

Atkinson, A.B. (1970), Poverty in Britain and the Reform of Social Security, Cambridge: Cambridge University Press.

Atkinson, A.B., and Bourguignon, F. (2001), 'Poverty and Inclusion from a World Perspective', in J. Stiglitz and P. Muet (eds.), Governance, Equity and Global Markets, Oxford: Oxford University Press, 151-66. 
Bailey, N. and Bramley, G. (2018), 'Introduction', in G. Bramley, and N. Bailey (eds.), Poverty and Exclusion in the UK: volume 2 - the dimensions of disadvantage, Bristol: Policy Press, $1-23$.

Baum, S. (1992), 'Poverty, Inequality, and the Role of Government: What Would Adam Smith Say?' Eastern Economic Journal, 18, 2, 143-56.

Bourguignon, F. (2019), 'Afterword: Growth, Inequality and Poverty Reduction', in A.B. Atkinson, Measuring Poverty around the World, Princeton: Princeton University Press, 218-246.

Bradshaw, J. (2011), 'Poverty', in, A. Walker, A. Sinfield and C. Walker (eds.), Fighting Poverty, Inequality and Injustice: a manifesto inspired by Peter Townsend, Bristol: Policy Press, 91-110.

Bramley, G. and Bailey, N. (2018), 'Conclusions and emerging themes', in G. Bramley and N. Bailey (eds.), Poverty and Exclusion in the UK: volume 2 - the dimensions of disadvantage, Bristol: Policy Press, 343-62.

Briggs, A. (1961), Social Thought and Social Action: a study of the work of Seebohm Rowntree, London: Longman.

Carr, J., Councell, R., Higgs, M., and Singh, N. (2014), Households Below Average Income: an analysis of the income distribution 1994/95-2012/13, London: DWP.

Clark, G. and Franklin, P. (2006), 'First principles: Poverty is relative and social exclusion matters', in Social Justice Policy Group, The State of the Nation Report, London: Conservative Party, 4-6.

Coates, D. and Bodington, S. (1976), 'Introduction', in Heller, A., The Theory of Need in Marx, London: Allison and Busby, 7-19.

Coates, D. and Silburn, R. (1973), Poverty: the forgotten Englishmen, (Second edition), Harmondsworth: Penguin.

Davis, A., Hirsch, D., Padley, M., Shepherd, C. (2020), A Minimum Income Standard for the United Kingdom 2020, York: JRF.

Deacon, A. (2002), Perspectives on Welfare, Buckingham: Open University Press.

Department of Housing, Communities and Local Government (2018), Analysis of the Determinants of House Price Changes, ad hoc publication, April 13, available at: https:// assets.publishing.service.gov.uk/government/uploads/system/uploads/attachment_data/ file/699846/OFF_SEN_Ad_Hoc_SFR_House_prices_v_PDF.pdf, [accessed 13.01.21]

Edmiston, D. (2021), 'Plumbing the Depths: the changing (socio-demographic) profile of UK poverty', Journal of Social Policy.

Engels, F. (1892), The Condition of the Working Class in England, London: Swan Sonnenschein.

Eurobarometer (2007), Poverty and Exclusion: 279, Brussels: European Commission.

Fifita, V., Najera, D., Gordon, D. and Nandy, S. (2017), Multidimensional Poverty in the Solomon Islands According to National Definitions, Briefing Paper to PSSC-SPC, Cardiff.

Fleischacker, S. (2004), On Adam Smith's Wealth of Nations, Woodstock: Princeton University Press.

Frey, B. and Stutzer, A. (2002), 'What Can Economists Learn from Happiness Research?' Journal of Economic Literature, 40, 2, 402-35.

George, H. (1879), Progress and Poverty: An Inquiry into the Cause of Industrial Depressions and of Increase of Want with Increase of Wealth, New York: Appleton and Co.

Gilbert, G. (1997), 'Adam Smith on the nature and causes of poverty', Review of Social Economy, 55, 3: 273-91.

Gordon, D. and Pantazis, C. (eds.) (1997), Breadline Britain in the 199os, Bristol: Summerleaze House.

Gordon, D., Levitas, R., Pantazis, C., Patsios, D., Payne, S., Townsend, P., Adelman, L., Ashworth, K., Middleton, S., Bradshaw, J. and Williams, J. (2000), Poverty and Social Exclusion in Britain, York: JRF.

Gould, A. (1988), Conflict and Control in Welfare Policy: the Swedish experience, London: Longman. 
Hallerod, B. (1994), A New Approach to the Consensual Measurement of Poverty, SPRC Discussion Paper No.50, Sydney: University of New South Wales.

Harris, B. (2000), 'Seebohm Rowntree and the measurement of poverty, 1899-1951', in J. Bradshaw and R. Sainsbury, (eds.), Getting the Measure of Poverty, Aldershot: Ashgate, $60-84$.

Hegel, G.W.F. (1975) [1820], Philosophy of Right, Oxford: Oxford University Press.

Hick, R. (2014), 'Poverty as Capability Deprivation: Conceptualising and measuring poverty in contemporary Europe', European Journal of Sociology, 55, 3, 295-323.

Hills, J. (2004), Inequality and the State, Oxford: Oxford University Press.

Karagiannaki, E. (2017), 'The Empirical Relationship Between Income Poverty and Income Inequality in Rich and Middle-Income Countries', CASEpaper 207, London: Centre for the Analysis of Social Exclusion.

Lansley, S. and Mack, J. (2013), Review of Niemietz, K. (2011), A New Understanding of Poverty, London: IEA, available at: https://www.poverty.ac.uk/sites/default/files/docs/Review\% 2520 Nimietz\%252020\%2520May\%2520sl\%26jm-final\%5B1\%5D.pdf [accessed 30/08/ 2020]

Lansley, S. and Mack, J. (2015), Breadline Britain, London: OneWorld.

Lebowitz, M. (2003), Beyond Capital: Marx's Political Economy of the Working Class, (Second edition), New York: Palgrave MacMillan.

Lister, R. (2021), Poverty, (Second edition), Cambridge: Polity.

McLean, I. (2006), Adam Smith: radical and egalitarian, Edinburgh: Edinburgh University Press.

Mack, J. and Lansley, S. (1985), Poor Britain, London: Allen and Unwin.

Marcuse, H. (1964), One-Dimensional Man, Boston, MA: Beacon Press.

Marshall, A. (1946), Principles of Economics, (Eighth edition), London: Macmillan.

Marshall, A. (1969), 'Three lectures on progress and poverty by Alfred Marshall', Journal of Law and Economics, 12, 1, 184-226.

Marx, K. (with Engels, F.) (1970), Selected Works, London: Lawrence and Wishart.

Marx, K. (2011) [1844], Economic and Philosophic Manuscripts of 1844, Blacksburg, VA: Wilder.

Nandy, S. and Pomati, M. (2015), 'Applying the Consensual Method of Estimating Poverty in a Low Income African Setting', Social Indicators Research, 124, 693-726.

Niemietz, K. (2011), A New Understanding of Poverty, London: IEA.

ONS (Office for National Statistics). (2020), Average household income, UK: financial year ending 2020: provisional, London: ONS.

Piachaud, D. (1981), 'Peter Townsend and the Holy Grail', New Society, 10 September, 419-21.

Pigou, A. (ed.) (1925), Memorials of Alfred Marshall, London: MacMillan.

Pomati, M. and Nandy, S. (2020), 'Measuring multidimensional poverty according to national definitions: Operationalising target 1.2 of the sustainable development goals', Social Indicators Research, 148, 105-26.

Portes, J. (2020), 'Measuring, monitoring and making progress: what targets should we have?', in Tucker, J. (ed.), Ending Child Poverty for Good: 2020 Vision, London: CPAG, 30-34.

Ravallion, M. (2016), The Economics of Poverty, Oxford: Oxford University Press.

Ravallion, M., and Chen, S. (2011), 'Weakly relative poverty', Review of Economics and Statistics, 93, 4, 1251-61.

Rowntree, B.S. (1901), Poverty: a study of town life, London: MacMillan.

Rowntree, B.S. (1937), The Human Needs of Labour, London: Longmans.

Rowntree, B.S. (1941), Poverty and Progress: a second social survey of York, London: Longmans. Saunders, P. and Wong, M. (2010), Measurement and Change in Deprivation and Exclusion in Australia, Methods Series No.11, Bristol: PSE/ESRC.

Schulz, W. (1843), Die Bewegung der Production, Winterthur: Wentworth. (Reprinted)

Sen, A. (1983), 'Poor, relatively speaking', Oxford Economic Papers, 35, 2, 153-69.

Shildrick, T. (2018), Poverty Propaganda: exploring the myths, Bristol: Policy Press.

Smith, A. (1976) [1759], The Theory of Moral Sentiments, Oxford: Oxford University Press. 
Smith, A. (1978) [1762-66], Lectures on Jurisprudence, Oxford: Oxford University Press.

Smith, A. (2012) [1776], An Inquiry into the Nature and Causes of the Wealth of Nations, Hertfordshire: Wordsworth.

Smith, C. (2020), Adam Smith, Cambridge: Polity.

Stănescu, I., and Dumitru, M. (2017), 'Poverty and social exclusion in Romania: a consensual approach to material deprivation', Quality of Life, 28, 1, 3-25.

Starks, B. and Junisbai, A. (2007), 'False Consciousness', in G. Ritzer (ed.), The Blackwell Encyclopaedia of Sociology, Oxford: Blackwell, 1568-70.

Townsend, P. (1954), 'Measuring Poverty', British Journal of Sociology, 5, 2, 130-37.

Townsend, P. (1958), 'A society for people', in N. Mackenzie (ed.), Conviction, London: MacGibbon and Kee, 93-120.

Townsend, P. (1962), 'The meaning of poverty', British Journal of Sociology, 13, 3, 210-27.

Townsend, P. (1970), 'Measures and explanations of poverty in high income and low income countries', in P. Townsend (ed.), The Concept of Poverty, London: Heinemann, 1-45.

Townsend, P. (1975), Sociology and Social Policy, Harmondsworth: Penguin.

Townsend, P. (1979), Poverty in the United Kingdom, Harmondsworth: Penguin.

Townsend, P. (1981), 'Peter Townsend replies', New Society, 17 September, 477-78.

Townsend, P. (1985a), 'A sociological approach to the measurement of poverty: a rejoinder to Amartya Sen', Oxford Economic Papers, 37, 4, 659-68.

Townsend, P. (1985b), 'Review of Mack, J. and Lansley, S. (1985) Poor Britain', Poverty, 61, 42-45.

Veit-Wilson, J. (1986), 'Paradigms of Poverty: a rehabilitation of B.S. Rowntree', Journal of Social Policy, 15, 1, 69-99.

Wong, H. and Saunders, P. (2012), Report of Research Study on Deprivation and Social Exclusion in Hong Kong, Hong Kong: Council for Social Service.

Wright, G. and Noble, M. (2013), 'Does widespread lack undermine the socially perceived necessities approach to defining poverty? Evidence from South Africa', Journal of Social Policy, 42, 1, 147-65. 